\title{
The Advantage of Being a Small Country on Economic Growth Spillovers: A Review on Spain and Portugal with ARDL Approach
}

\author{
MURAT EMIKKÖNEL* \\ Faculty of Economic and Administrative Science, Economics Department, \\ University of Kocaeli, Turkey \\ ORCID: 0000-0002-8415-0510 \\ DANIEL MEYER \\ College of Business and Economics, University of Johannesburg \\ PO Box 524, Auckland Park \\ SOUTH AFRICA \\ AYHAN ORHAN \\ Faculty of Economic and Administrative Science, Economics Department, \\ University of Kocaeli, Turkey \\ ORCID: 0000-0002-8109-4306 \\ GUALTER COUTO \\ School of Business and Economics and CEEAplA \\ University of Azores \\ 9500-321 Ponta Delgada, Portugal \\ PORTUGAL \\ ORCID: https://orcid.org/0000-0001-5560-5101 \\ RUI ALEXANDRE CASTANHO \\ Faculty of Applied Sciences, WSB University \\ 41-300 Dabrowa Górnicza \\ POLAND \\ and \\ College of Business and Economics, University of Johannesburg \\ PO Box 524, Auckland Park \\ SOUTH AFRICA
}

\begin{abstract}
This study investigates Spain's role in Portugal's economic development and analyzes the assumption that Spain's import from Portugal is the factor that increases Portugal's per capita income the most. Apart from these reasons, there are several other motivations to focus on foreign trade between Spain and Portugal. The first is to examine the impact on Portugal of the increases in GDP, exports and imports of Spain, which is the major country and borders Portugal. Second, this study aims to test the growth spread. According to the test results, the economic growth of Spain positively affects the growth of Portugal in the long and short term. In addition, it was concluded that the share of imports has more positive effects than exports in the long run. It shows that the deviation in the variables according to the error correction term result converges to only 85 percent in the $\mathrm{t}$ period. The findings are also consistent with previous research supporting the economic integration arguments that emerged as a result of trade relations. In addition, in this direction, the economic and political meetings to be held between the two countries and the actions to be taken as a result of these meetings can create an environment where both countries can win.
\end{abstract}

Key-Words: - Economic Growth Spillovers, Economic Growth and Development, International Trade, Export and Import, Small Country, Spain-Portugal, ARDL Bounds Test.

Received: July 24, 2021. Revised: December 30, 2021. Accepted: January 15, 2022. Published: January 16, 2022. 


\section{Introduction}

The Spanish economy has undergone major changes over the past forty years. With these changes, the country is vital for the EU in tourism, agriculture, and industry [1]. Considering its economic size, it is the fifth-largest economy in the EU and fourteenth in the world. Spain is a modern knowledge-based economy represented by the services sector, equalling $75 \%$ of its business operations. It has a highly competitive, young, highly skilled, and highly motivated population in Western Europe [2]. The most important sectors of the Spanish economy are wholesale and retail trade, transportation, accommodation and food services (23.4\%), public administration, defense, education, human health and social work activities (18.9\%), and industry $(17.8 \%)$. [3].

Portugal, which could be described as a poor economy in Europe until the 1990s, grew more compared to the economies of similar countries by the 2000s [4]. Between 2001-10, GDP growth fell an average of $0.6 \%$, and unemployment tripled. Correction of macroeconomic and financial imbalances started seriously in 2011. Despite significant losses in foreign trade, the current account deficit was narrowed significantly due to both the decrease in import volume and strong export performance [5]. As one of the most incomegenerating mushroom producers in the world today, Portugal is in the high-income group [6]. Portuguese economy primarily exports motor vehicle parts, electrical machinery, petroleum and mineral fuels, industrial machinery, and plastics, respectively. The most imported products are motor vehicle parts, petroleum and mineral fuels, industrial machinery, electrical machinery, and plastics, respectively [7].

Historically on the southern border of Europe, the two countries with a less developed economy than their northern partners have a rich national history. Spain and Portugal were in limited relations with Europe until they became a member of the European economic community. After membership, the two entered deeper economic ties between themselves and Europe [8]. They work with similar views within the EU for stronger relations with the Mediterranean and Latin American countries [9]. As a result of increased relations, Spain ranked first in exports and imports for the Portuguese economy [10]. In this context, export and import shares, which are included in the analysis part of the study, are given in Figure 1.

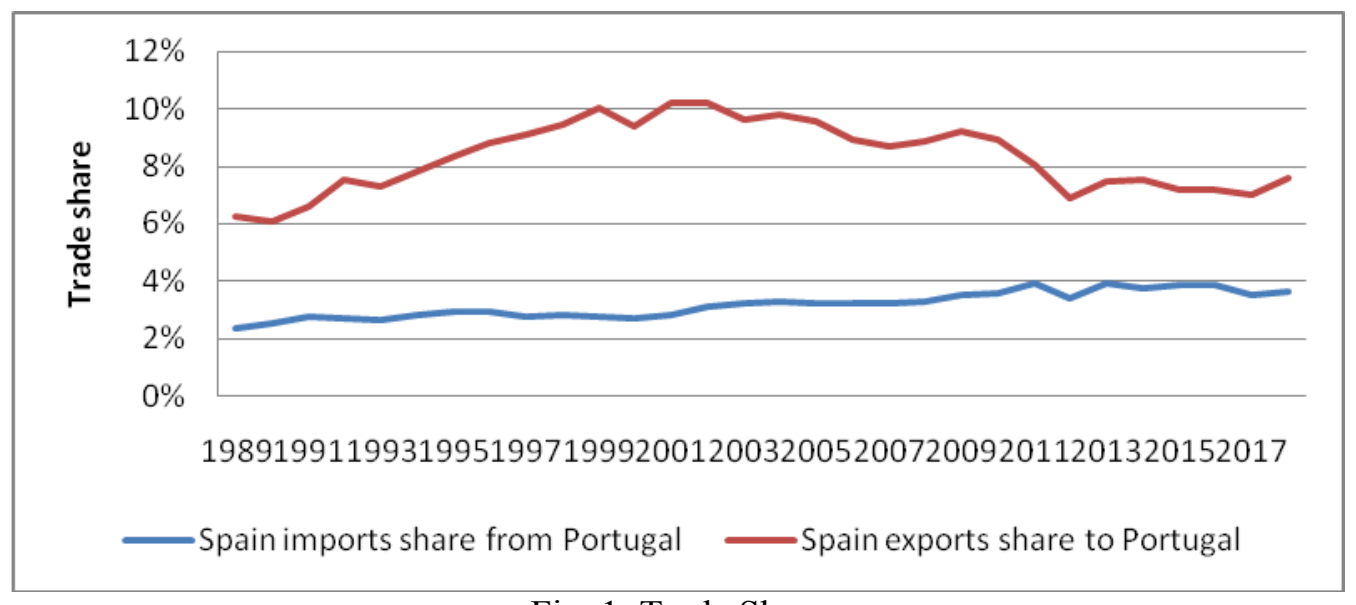

Fig. 1: Trade Share

Source: The data was compiled by the authors from World Bank.

When Figure 1 is analyzed, it is seen that the rate of Spain's exports to Portugal is 2.6 times higher than the imports. The striking point in the figure is that while the share of imports increases regularly, the percentage of exports fluctuates. After the global economic crisis in 2008, Portugal's share in Spain's exports increased after this year even though it was at the bottom level in 2012. As of 2017, this rate approached the figures back in 2012 but increased again in the following year. Several factors have been affecting the economic performance of Spain and Portugal recently and changing its economy, and these factors can be examined under four headings. The first is the oil crisis in the early 1970 s, the second is the process of connecting to the community that goes back to the end of 1985 , the third is the period until the introduction of the euro, and the last one is the period that includes the 
effects of the major economic and financial crisis triggered by the American mortgage market crisis. In general, both Spain and Portugal adapt to European economic dynamism. When Europe loses its economic dynamism, both Portugal and Spain lose dynamism accordingly. However, Portugal is more affected by negative consequences [11].
The close relationship in both the historical and economic relations of the two countries is reflected in the per capita income. When Figure 2 is analyzed, it is seen that Spain and Portugal's per capita income move together. However, the same proportionality increases in favor of Spain during the enlargement periods.

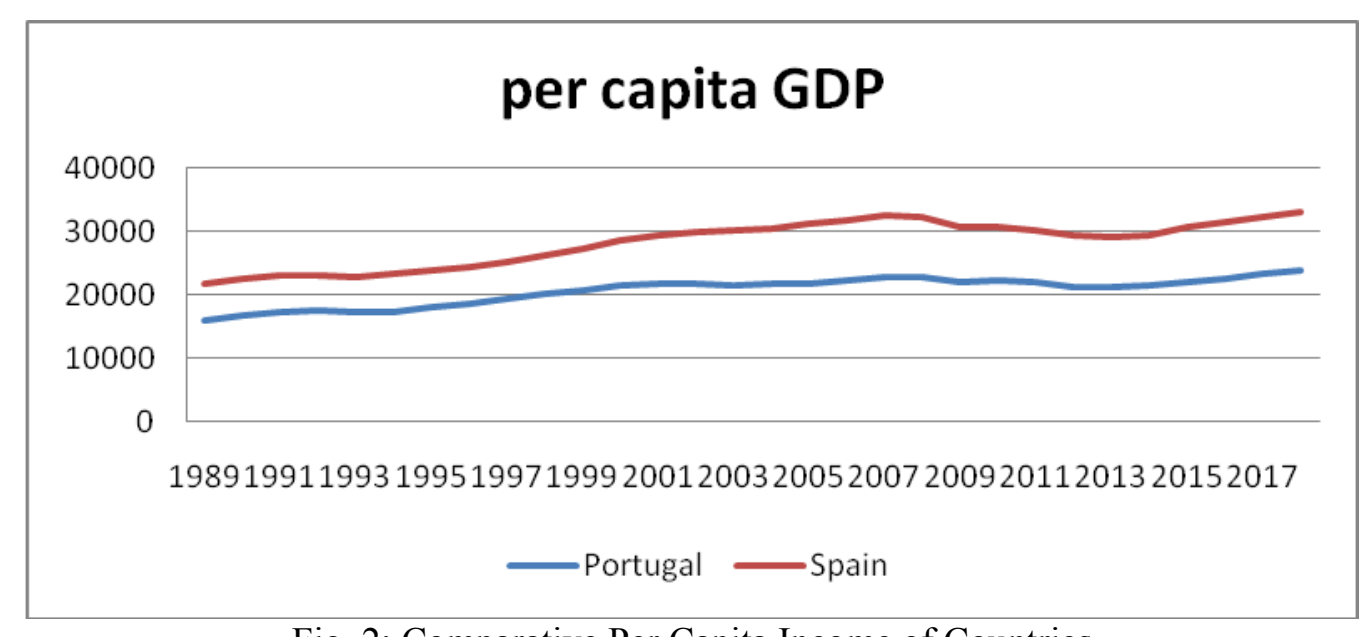

Fig. 2: Comparative Per Capita Income of Countries

Source: The data was compiled by the authors from the World Bank.

This study focused on the Spanish-Portuguese couple for three reasons. The primary reason is to examine the impact on Portugal of the increase in Spain's share of exports and imports from Portugal, in addition to the increase in Spain's GDP. Although some studies in the literature research the economic relationship between Spain and Portugal, there is no study examining this relationship in this relevant respect. Second, this study tests growth spread rather than macroeconomic links, unlike other studies. Thirdly, it is expected that countries are economically interdependent as they are close neighbors. In this context, considering Spain and Portugal's close commercial and economic relations, the study analyzes the effect of Spain's per capita income and increase in export and import shares on the Portuguese economy with the ARDL border test approach for long and short terms.

\section{Literature Review}

There are studies in the literature that focus on Export-Led Growth and Import-Led Growth. Studies aiming to confirm the positive impact of exports on economic growth were conducted by Findlay [12], Krueger [13], and Darrat [14], which test for cointegration using the rank correlation. Furthermore, Balassa [15], and Ram [16] estimated regression equations for GDP (GNP) where the export is considered as the independent variable besides other variables, such as capital and labor. Furthermore, Michaely [17], Feder [18], Marin [19], and Thornton [20] has found that countries that export the majority of their final goods grow more quickly. The increase in exports also encourages exports by providing technological spillovers and other externalities in the economy. Models by Grossman and Helpman [21], RiveraBatiz and Romer [22], and Romer [23] assume that expanded international trade increases the number of specialized inputs, increasing growth rates as economies become open to international trade. Buffie [24] evaluates the impact of shocks in exports on export-led growth. According to Bhagwati [25], increased trade results in more income (increased GDP) and more income further increases trade. Ramos [26] conducted a Granger causality analysis for the Portuguese economy based on the Johansen cointegration and error correction model. As a result, the cointegration between export growth and economic growth suggests long and short-term bidirectional causality relationships. However, no correlation between import and export growth was detected. Awokuse [27] tested the link between exports, imports, and GDP growth through an augmented production function. The Granger causality test provided evidence for ELG and Growth-Led Export (GLE) 
for Bulgaria. However, for the Czech Republic, a unidirectional relationship from exports and imports to GDP growth was identified. For Poland, only ILG was validated.

For China, Mah [28], tested ELG using the ARDL model for the statistic of Pesaran and Shin [29]. The results were in favor of a long-term bidirectional relationship between real GDP growth and export growth. The same finding was also obtained by Shan and Sun [30].

Hye and Boubaker [31] investigated the relationship between exports, imports, and economic growth for Tunisia between 1960 and 2008 by applying the ARDL test to determine the direction of causality in the long term. The analysis results found a unidirectional causality between exports and economic growth and bilateral causality between imports and economic growth. They also noted that the growth based on exports and imports was valid in Tunisia. Mendonça [11] researched the economic performance of Spain, Portugal, and Europe in his study. The two countries' economies are shaped by various shocks that profoundly affect the internal and external dynamics. Spain was more successful than Portugal in complying with European Union regulations. While the Spanish economy became stronger in the European Union process, the sensitivity of the Portuguese economy increased. Lastly, Kalai and Zghidi [32] addressed the relationship between foreign investment, international trade, and economic growth for the 15 countries in the MENA region between 1999 and 2012 with the ARDL test and vector error correction model. According to the analysis results, they concluded that the main factor affecting economic growth in the long run in MENA countries is foreign direct investments. Kumar [33], in addition to the impact of physical capital and foreign direct investment on growth, India examines the dynamic spillover of China's bilateral trade using the ARDL method. The results of the analysis indicated that bilateral trade has a significant long-term effect on the growth rate of the two countries as measured by GDP per capita. Kumar [34] examined the exports and imports of India, the largest economy in the South Asian Regional Cooperation Association, to/from South Asia and its contribution to these countries. In his study, which he analyzed with the ARDL bounds test using data from 1990-2016, he concluded that India's economic growth and regional trade have short- and long-term spillovers on the economic growth of Bangladesh, Sri Lanka, Nepal and Bhutan.

\section{Data and Methodology}

The ARDL procedure is superior to the other cointegration tests since it allows to overcome the problem of endogeneity caused by the Granger procedure and allows for long-run relationship testing. In addition to this, the ARDL test for the long-run relationship has no restriction on the integration order of the variables, i.e., variables with different order of integration, nonintegrated, or fractionally cointegrated can be used. Moreover, the ARDL technique can be performed on a smallsized sample [31]. With these superior features, the study measures the effect of Spain on the Portuguese economy using the ARDL method. Since Spain is larger than Portugal in terms of population and GDP, per capita income is used as a variable in the analysis. Accordingly, the effect of a change (increase) in Spain's per capita income on growth spread in Portugal's per capita income is examined. The study is carried out using annual data covering 1989-2018. Four variables are used in the model. Portugal's per capita income is an independent variable obtained from the World Bank database. There are three dependent variables: the per capita income of Spain, the share of Spain's exports to Portugal in its total exports, and the share of Spain's imports from Portugal in total imports. Spain's per capita income is also taken from the World Bank database, and export and import shares from the World Integrated Trade Solution online database. $Y_{t}$ and $X_{t}$ represent the dependent country's GDP growth rate and the independent country's GDP growth rate to show economic growth, respectively. $E X_{t}$ represents the share of Spain's exports to Portugal in total exports, and $I M_{t}$ represents the share of imports from Portugal in total imports. The relationship between the variables is given in equation 1 .

$Y_{t}=\alpha_{0}+\beta_{1} E X_{t}+\beta_{2} I M_{t}+\beta_{3} X_{t}+\varepsilon_{t}$

$Y_{t}$ denotes dependent country per capita GDP

$X_{t}$ denotes independent country per capita GDP

$E X_{t}$ denotes the share of Spain's exports to Portugal in its total exports.

$I M_{t}$ denotes the share of Spain's imports from Portugal in total imports.

$\varepsilon_{t}$ denotes error term. 


\section{Empirical Findings}

\subsection{Unit Root Test Results}

For the data analysis in the study, firstly, stationary properties are examined. Stationary is decided based on whether the stochastic process varies depending on time in time series analysis. If the nature of the probabilistic process changes over time, it means that the series is not stationary. As a result of the fact that the series is not stationary, the problem of false regression arises [35]. In such a situation, the real relationship between the series cannot be measured. In this context, the series to be examined were analyzed with the Augmented Dickey-Fuller [36] unit root test developed by Dickey-Fuller in 1981 to obtain consistent and reliable analysis results. The test results are presented in Table 1.

Table 1. ADF Unit Root Test Results (Level and first difference)

\begin{tabular}{|l|l|l|l|l|l|l|}
\hline & \multicolumn{2}{|c|}{ GDP } & \multicolumn{2}{c|}{ EXPORT } & IMPORT \\
\hline & Level & First difference & Level & First difference & Level \\
& Without & Without & Without & Without & Without \\
Constant-Trend & Constant-Trend & $\begin{array}{l}\text { Without } \\
\text { Constant-Trend } \\
\text { Constant-Trend }\end{array}$ \\
\hline Country & & & & & \\
\hline Spain & 1.0367 & -2.0638 & - & - & - & \\
& 0.9170 & $0.0394 * *$ & & & - \\
\hline Portugal & 1.3853 & -2.5727 & 0.2175 & -4.6533 & -3.4890 \\
& 0.9548 & $0.0121^{* *}$ & 0.7423 & $0.0000^{* * *}$ & $0.0595^{*}$ \\
\hline
\end{tabular}

Note: ***, **, and *indicate significance at 1\%, 5\%, and $10 \%$ significance levels, respectively.

Looking at Table 1, the GDP variable is stationary at the first difference for Spain and Portugal and is statistically significant at the $5 \%$ level. The share of Spain's exports to Portugal is stationary at the first difference and statistically significant at the $1 \%$ level. The share of Spain's imports from Portugal is stationary both in level and in the first difference, but the statistical significance levels are $10 \%$ and $1 \%$, respectively. Table 1 shows that the ARDL bounds test can be performed in the study because the series is stationary at different levels, and it does not need to be stationary at the same level compared to the Johansen-Juselius and EngleGranger [37] cointegration tests. The assumption that the Johansen-Juselius [38] and Engle-Granger cointegration tests are evenly stationary as the prerequisite is the weakness of these tests. However, Pesaran et al. [29] and then Pesaran et al. In the ARDL bounds test developed by (2001), the lack of a condition requiring the series to be stationary at the same level provides convenience in the studies [39]. Additionally, the ARDL bounds test can be used in a small observation dataset [40]. The ARDL bounds test consists of two stages. The first step is to determine the existence of a longterm relationship between the variables. After the existence of a long-term relationship is detected in the first stage, the long-term and short-term causality relationship is estimated in the second stage within the framework of the error correction term (ECT).
This study adapted the form of the model presented in equation 2 to determine the existence of a longterm relationship between the variables:

$$
\begin{aligned}
& \Delta Y_{t}=\alpha_{0}+\rho_{1} Y_{t-1}+\rho_{2} \text { Export }_{t-1}+\rho_{3} \\
& \text { Import }_{t-1}+\rho_{4} X_{t-1}+\sum_{i=1}^{a} \gamma_{1 i} \Delta Y_{t-i}+ \\
& \sum_{i=0}^{b} \gamma_{2 i} \Delta \text { Export }_{t-i}+\sum_{i=0}^{c} \gamma_{3 i} \Delta \text { Import }_{t-i}+ \\
& \sum_{i=0}^{d} \gamma_{4 i} \Delta X_{t-i}+\varepsilon_{t}
\end{aligned}
$$

where $\alpha_{0}$ is the constant term, $\varepsilon_{t}$ is the error term, $\Delta$ are first difference of the series, $\rho_{1,2,3,4}$ are longrun multipliers, and a, b, c, and d represent the lag length of the variables.

The test of the existence of cointegration in the ARDL model is based on the F statistic. With calculated $\mathrm{F}$ statistics

$H_{0}: \rho_{1}=\rho_{2}=\rho_{3}=\rho_{4}=0$ (No cointegration.)

$H_{1}: \rho_{1} \neq \rho_{2} \neq \rho \neq \rho_{4} \neq 0$ (Cointegrated.) hypotheses are tested. Based on the $F$ statistics results obtained from the test results, it is decided whether the $\mathrm{H}_{0}$ hypothesis can be rejected or not. If the result of the $\mathrm{F}$ statistic is above the limit, $\mathrm{H}_{0}$ is rejected, and there is a cointegration result. If the $\mathrm{F}$ statistic result is below the limit, $\mathrm{H}_{0}$ cannot be rejected, and it is concluded that there is no cointegration. If the result is between the lower limit and the upper limit, no interpretation can be 
Table 2. The ARDL Bounds Test and Diagnostic Tests

\begin{tabular}{|c|c|c|c|c|c|c|c|}
\hline & ARDL & $\mathrm{F}$ & \multicolumn{4}{|c|}{ Diagnostic tests } & \multirow[t]{2}{*}{ Remarks } \\
\hline & & & $\underset{X^{2}}{\text { Normality }}$ & $\begin{array}{c}\text { Heteroscedasticity } \\
X^{z}\end{array}$ & $\begin{array}{c}\text { Serial } \\
\text { Correlation } \\
X^{2}\end{array}$ & $\begin{array}{c}\text { Ramsey } \\
\text { Reset Tests }\end{array}$ & \\
\hline F (PRT/ESP) & $1,4,5,5$ & 7.038591 & $\begin{array}{c}0.268086 \\
(0.874552) \\
\end{array}$ & $\begin{array}{r}0.025007 \\
(0.8743) \\
\end{array}$ & $\begin{array}{l}1.842590 \\
(0.1746) \\
\end{array}$ & $\begin{array}{r}1.214656 \\
(0.3206) \\
\end{array}$ & Cointegrated \\
\hline $\begin{array}{c}\text { Significance } \\
\text { Level }\end{array}$ & \multicolumn{7}{|c|}{ Critical values $\mathrm{T}: 35$} \\
\hline $\mathrm{F}(\mathrm{PRT} / \mathrm{ESP})$ & \multicolumn{4}{|c|}{ Lower bounds I(0) } & \multicolumn{3}{|c|}{ Upper bounds I(1) } \\
\hline $1 \%$ & \multirow{2}{*}{\multicolumn{4}{|c|}{$\begin{array}{c}5.333 \\
3.71\end{array}$}} & \multirow{2}{*}{\multicolumn{3}{|c|}{$\begin{array}{l}7.063 \\
5.018\end{array}$}} \\
\hline $5 \%$ & & & & & & & \\
\hline $10 \%$ & \multicolumn{4}{|c|}{3.008} & \multicolumn{3}{|c|}{4.15} \\
\hline
\end{tabular}

Considering the results of $\mathrm{F}$ statistics given in Table 2, it is concluded that there is a long-term cointegration at the five percent level. According to the diagnostic test results, it was determined that there was no variance, autocorrelation problem, and model building error in the model, and the model showed a normal distribution. In other words, the model is not set up incorrectly and the reliability of the information obtained as a result of the established model is based on solid foundations.

After long-term cointegration is determined among the variables, the long and short-term coefficients of the variables can be calculated. The relationship of variables in the short run is determined by the error correction model. The error correction model equation includes the first differences of the variables and the one-time delayed errors of the cointegration regression. The advantage of using an error correction model is that it reveals short- and long-term causality and determines the imbalance between the variables, besides fixing them [41]. The adapted form of the error correction model is presented in equation 3 .

$$
\begin{aligned}
& \Delta Y_{t}=\alpha_{0}+\sum_{i=1}^{a} \gamma_{1 i} \Delta Y_{t-i}+\sum_{i=0}^{b} \gamma_{2 i} \Delta \text { Export }_{t-i} \\
& +\sum_{i=0}^{c} \gamma_{3 i} \Delta \text { Import }_{t-i}+\sum_{i=0}^{d} \gamma_{4 i} \Delta X_{t-i}+\beta E C T_{t-1} \\
& +\varepsilon_{t}
\end{aligned}
$$

$E C T_{t-1}$ shows a time-lagged value of the series of error terms derived from the long-term relationship. $\beta$ coefficient shows the rate of adaptation of the system to long-term balance after shocks occurring in the short term [42]. Error correction term (ECT) coefficient should be negative and statistically significant. It is also expected to be between 0 and 1 [42]. However, if it is between -1 and -2 , the variables provide convergence with decreasing fluctuation each time [43].

\subsection{Long and Short-Run Test Results}

After determining that there is cointegration in the variables taken for Spain and Portugal, the ARDL test was applied within the framework of error correction (ECT) to determine the variables' long and short term coefficients. Long and short term test results of Portugal are given in Table 3 . According to the test results, the economic growth of Spain positively affects the growth of Portugal in the long run. In the short term, it affects positively in the current period and in the three delay periods, while it affects negatively in one delayed and two delayed periods. The share of exports affects positively in the long and short term. While the share of imports has more positive effects than exports in the long run, it has a negative effect in the short run. The error correction term was found to be -0.85 . This result indicates that the deviation in the variables in the t-1 period converged only 85 percent in the $t$ period. 
Table 3. Short- and Long-Run Relationship for Portugal

\begin{tabular}{|c|c|c|c|}
\hline \multicolumn{2}{|c|}{ Long-run relationship } & \multicolumn{2}{|c|}{ Short-run relationship } \\
\hline Variable & Coefficient & Variable & Coefficient \\
\hline Export & $\begin{array}{l}544.8157 \\
(0.0014)^{* * *}\end{array}$ & $\Delta$ Export & $\begin{array}{l}285.3311 \\
(0.0025)^{* * *}\end{array}$ \\
\hline Import & $\begin{array}{l}2241.793 \\
(0.0016)^{* * *}\end{array}$ & $\Delta$ Export (-1) & $\begin{array}{r}52.18409 \\
(0.4437) \\
\end{array}$ \\
\hline \multirow[t]{13}{*}{$\mathrm{X}$} & $\begin{array}{l}0.409388 \\
(0.0004)^{* * *}\end{array}$ & $\Delta$ Export (-2) & $\begin{array}{l}119.8903 \\
(0.0948)^{*}\end{array}$ \\
\hline & & $\Delta$ Export (-3) & $\begin{array}{l}348.7434 \\
(0.0010)^{* * *}\end{array}$ \\
\hline & & $\Delta$ Export (-4) & $\begin{array}{l}168.8244 \\
(0.0438)^{* *}\end{array}$ \\
\hline & & $\Delta$ Import & $\begin{array}{l}-631.5739 \\
(0.0114)^{* *}\end{array}$ \\
\hline & & $\Delta \operatorname{Import}(-1)$ & $\begin{array}{l}-2508.944 \\
(0.0004)^{* * *}\end{array}$ \\
\hline & & $\Delta \operatorname{Import}(-2)$ & $\begin{array}{l}-2074.591 \\
(0.0015)^{* * *}\end{array}$ \\
\hline & & $\Delta \operatorname{Import}(-3)$ & $\begin{array}{l}-1900.858 \\
(0.0009)^{* * *}\end{array}$ \\
\hline & & $\Delta \operatorname{Import}(-4)$ & $\begin{array}{l}-883.2378 \\
(0.0072)^{* * *}\end{array}$ \\
\hline & & $\Delta \mathrm{X}$ & $\begin{array}{l}0.415465 \\
(0.0003)^{* * *}\end{array}$ \\
\hline & & $\Delta \mathrm{X}(-1)$ & $\begin{array}{l}-0.132181 \\
(0.0804)^{*}\end{array}$ \\
\hline & & $\Delta \mathrm{X}(-2)$ & $\begin{array}{l}-0.112378 \\
(0.1475)\end{array}$ \\
\hline & & $\Delta \mathrm{X}(-3)$ & $\begin{array}{l}0.130222 \\
(0.0585)^{*}\end{array}$ \\
\hline & & ECT(-1) & $\begin{array}{l}-0.850467 \\
(0.0006) * * *\end{array}$ \\
\hline
\end{tabular}

Note: $* * *, * *$, and $*$ indicate significance at $1 \%, 5 \%$, and $10 \%$ significance levels, respectively.

Considering the figure 1 above, although Spain's export share to Portugal has fluctuated over the years, its share in 2018 is at a point equivalent to the initial year. However, the share of imports has followed an increasing course over the years. As seen in our results, the share of imports is more influential than the share of exports. When we look at the products imported by Spain to Portugal, the first five rows are vehicles other than railway or tramway wagons and their parts and components; Machinery, mechanical devices, nuclear reactors, boilers, parts thereof; Plastics and articles thereof; Mineral fuels, mineral oils and their distillation products, bituminous substances, mineral; Iron and steel products are included. The share of these products in their trade is $12 \%, 8 \%, 7 \%, 5 \%$, and $4.6 \%$, respectively. When we look at the products exported by Spain from Portugal, the first five ranks are "Vehicles other than railway or tramway wagons and their parts and parts; Machinery, mechanical devices, nuclear reactors, boilers, their parts and parts; Electrical machinery and equipment and their parts; Plastics. and goods; Mineral fuels, mineral oils and products obtained from their distillation, bituminous substances, mineral" products. The share of these products in their trade is $8.3 \%, 7.9 \%, 7.4 \%, 5.5 \%$ and $4.5 \%$, respectively. Although four of the groups of goods it exports and imports are the same products, Portugal is a net exporter of these products against Spain. As of 2020, Portugal's net trade surplus value against Spain is approximately 10.3 billion dollars.

Spain's per capita income, the effect of changes in export and import shares on Portugal's per capita income are collectively presented in Figure 3 . The cumulative sum (CUSUM) tests of the study are given in Annex 1. 
Long Run Spillovers

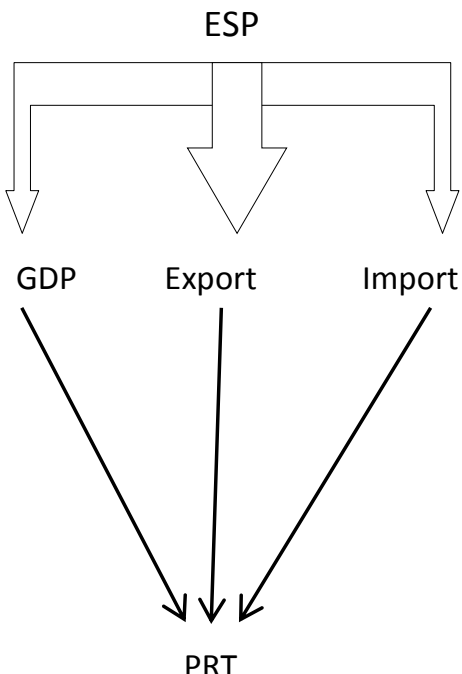

Short Run Spillovers

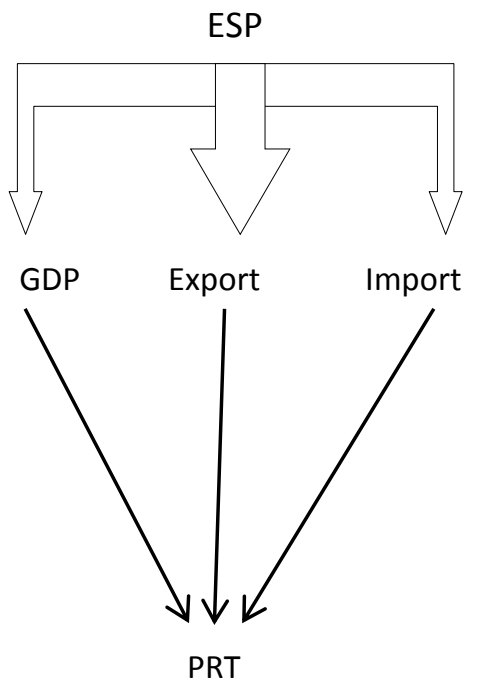

Fig. 3: The Impact of Spain's Gdp, Export Share, and Import Share on Portugal

\section{Conclusions and Recommendations}

Spain and Portugal, which joined the European Community in 1986, have rich historical and economic relations. Based on this close economic relationship, the effect of Spanish trade data and economy on the Portuguese economy was examined in the study. While the studies in the literature analyze bilateral trade, they sometimes consist of studies to find the factors that can be effective in the trade between the two countries. Sometimes, the effects on bilateral trade are analyzed directly by the amount of exports and imports or the monetary values of these amounts. The feature that distinguishes this study from other studies is that it measures the economic growth performance of the partner country for bilateral foreign trade, taking into account the export of the big country to the partner country and the share of imports from it in all exports and imports. The results reveal that Spain's exports, imports, and economic growth significantly increase Portugal's economic growth. As a result, the increase in Spain's per capita income positively affects Portugal's per capita income in the long run. In the short term, the increase in Spain's per capita income in the current period and the three lagged periods positively affects Portugal's per capita income, while in one lagged period, it affects negatively. The share of exports affects positively in the long- and shortterm. While the share of imports has more positive effects than exports in the long run, it has a negative effect in the short run. This is because Spain has a 25 percent share in Portugal's total exports.
Additionally, the fact that Portugal prefers imported products from Spain causes external reflection in trade, which therefore increases the export of Portugal. The findings are also consistent with previous research supporting the economic integration arguments that emerged as a result of trade relations. Based on these results, Portugal can increase its market share in the region by increasing its exports to Spain in the long term and positively affecting its economy. However, a contraction in the Spanish economy in the future could affect Portugal more negatively. Hence, Portugal needs to focus on market and product diversification. In addition, in this direction, the economic and political meetings to be held between the two countries and the actions to be taken as a result of these meetings can create an environment where both countries can win. This study investigated the data of Spain and Portugal. With the addition of different countries to the analysis in future studies, results can be diversified. Consequently, evaluations can be made by analyzing different variables for these two countries.

\section{Acknowledgements:}

This research was partially funded by the program of the Minister of Science and Higher Education titled "Regional Initiative of Excellence" in 20192022 , project number 018/RID/2018/19, the amount of funding PLN 10788 423,16. Moreover, our thanks also to the Portuguese national funds through FCT - Fundação para a Ciência e a Tecnologia, I.P., project number UIDB/00685/2020. 


\section{References:}

[1] Harrison, J., Corkill, D. (2016), Spain: a modern European economy. Routledge.

[2] http://www.investinspain.org/invest/en/whyspain/attractive-economy/index.html

[3] https://europa.eu/european-union/about$\mathrm{eu} /$ countries/membercountries/spain en\#trade-and-economy

[4] Duarte, A., Simões, M. (2011), Inequality and growth: Relevant Links for the Portuguese Economy. Radović-Marković M, Red epagić S, Andrade JS, Teixeira P (eds) Serbia and the European Union: Economic lessons from the new member states. Institute of Economic Sciences, Belgrade, 167-84.

[5] Pina, A., Abreu, I. (2012), Portugal: Rebalancing the Economy and Returning to Growth Through Job Creation and Better Capital Allocation.

[6] http://www.oecd.org/economy/portugaleconomic-snapshot/

[7] https://globaledge.msu.edu/countries/portugal/tra destats

[8] Cunha, A. (2018), Portugal, Spain, and Europe: from the Parallelism of the Accession Negotiations to the Capitalisation of the Third Enlargement of the European Economic Community. Relações internacionais.

[9] Raimundo, A., Mestres, L. (2018), Iberia: Spain and Portugal.

[10] https://data.worldbank.org/

[11] Mendonça, A. (2018), Portugal, Spain, the Euro and the International financial crisis. http://hdl.handle.net/11067/4422

[12] Findlay, R. (1984), Growth and Development in Trade Models, in R Jones and P B Kenen (Eds.), Handbook of International Economics, Vol. 1, North-Holland, Amsterdam.

[13] Krueger, A.O. (1985), The Experience and Lessons of Asia Superexporters, in V Corbo, A O Krueger and F Ossa (Eds.), Export-Oriented Development Strategies: The Success of Five Newly Industrialized Countries, Westview Press, London.

[14] Darrat, A. F. (1986), Trade and Development: The Asian Experience The Cato Journal, 6: 695-699.

[15] Balassa B (1985), Exports, Policy Choices, and Economic Growth in Developing Economies After the 1973 Oil Shock Journal of Development Economics, 18: 23-35.

[16] Ram, R. (1985), Exports and Economic Growth: Some Additional Evidence Economic Development and Cultural Change, 33(2) 415425 .
[17] Michaely, M. (1977), Exports and growth: an empirical investigation J. Dev. Econ 40: 49-53.

[18] Feder, G. (1982), On exports and economic growth. J. Dev. Econ. 12, 59-73.

[19] Marin, D. (1992), Is the export-led growth hypothesis valid for industrialized countries? Rev. Econ. Stat. 74: 678-688.

[20] Thornton, J. (1996). Cointegration, causality and export-led growth in Mexico. Econ. Lett. 50: 413-416.

[21] Grossman, G., Helpman, E. (1991), Innovation and Growth in the Global Economy, Cambridge, MA: MIT Press,

[22] Rivera-Batiz, L., Romer, P. (1991), Economic integration and endogenous growth. Q. J. Econ. 106: 531-556.

[23] Romer, P. (1990), Endogenous technological change. J. Polit. Econ. 98: 71-102.

[24] Buffie E. (1992) On the condition for exportled growth. Canadian Journal of Economics 25: 211- 225.

[25] Bhagwati, J. (1988), Protectionism, Cambridge, MA, MIT Press,

[26] Ramos, F.F.R. (2001), Exports, Imports, and Economic Growth in Portugal: Evidence from Causality and Cointegration Analysis Economic Modelling, 18: 613-623

[27] Awokuse T.O. (2007), Causality Between Exports, Imports, and Economic Growth: Evidence from Transition Economies Economics Letters, 94: 389-395.

[28] Mah, J.S. (2005), Export Expansion, Economic Growth and Causality in China Applied Economics Letters, 12(2): 105-107.

[29] Pesaran, M., Shin, Y. (1999), An Autoregressive Distributed Lag Modeling Approach to Cointegration Analysis, In Econometrics and Economic Theory in the 20th Century: The Ragnar Frisch Centennial Symposium, edited by S. Strom, 371-413. Cambridge: Cambridge University Press.

[30] Shan, J., Sun, F. (1998), On the Export-Led Growth Hypothesis: The Econometric Evidence from China Applied Economics 30: 1055-1065.

[31] Hye, Q.M.A., Boubaker, H.B.H. (2011), Exports, imports and economic growth: an empirical analysis of Tunisia The IUP Monetary Economics, 9 (1): 6-21.

[32] Kalai, M., Zghidi, N. (2019). Foreign Direct Investment, Trade, and Economic Growth in MENA Countries: Empirical Analysis Using ARDL Bounds Testing Approach. Journal of the Knowledge Economy. 10: 397-421 
[33] Kumar, R. (2019), "India-China: Changing Bilateral Trade and its Effect on Economic Growth." Singapore Economic Review. doi:10.1142/S021759081950005X. 33

[34] Kumar, R. (2020), India \& South Asia: Geopolitics, regional trade and economic growth spillovers, The Journal of International Trade \& Economic Development, 29:1, 69-88, DOI: $10.1080 / 09638199.2019 .163612134$

[35] Granger, C.W.J., Newbold, P. (1974), Spurious Regressions in Econometrics Journal of Econometrics 2: 111-120.

[36] Dickey. D.A., Fuller W.A. (1981), Likelihood ratio statistics for autoregressive time series with a unit root. Econometrica, 49(4): .10571072. http://dx.doi.org/10.2307/1912517

[37] Engle, R., Granger, C. (1987), Co-integration and error-correction representation, estimation and testing. Econometrica 55(2): 251-276.

[38] Johansen, S. (1988), Statistical Analysis Of Cointegration Vectors Journal of Economic Dynamics and Control, 12: 231-254.

[39] Pesaran, M., Shin, Y., Smith, R.J. (2001), Bounds Testing Approaches to the Analysis of Level Relationships Journal of Applied Econometrics 16(3): 289-326.
[40] Kamaruddin, R., Jusoff, K. (2009), An ARDL approach in food and beverages industry growth process in Malaysia. International Business Research, 2(3): 98-107.

[41] Enders, W. (1995), Applied Econometric Time Series, John Wiley\&Sons, Inc., New York 365366.

[42] Oteng-Abayie, E.F., Frimpong, J.M. (2006), Aggregate import demand and expenditure components in Ghana: An Econometric Analysis. Online at https://mpra.ub.unimuenchen.de/599/ MPRA Paper No. 599, pp. 10

[43] Narayan, P.K., Smyth, R. (2006), What Determines Migration Flows from LowIncome to High-Income Countries? An Empirical Investigation of Fiji-U.S. Migration 1972-2001 Contemporary Economic Policy 24(2): 332-342.

\section{Creative Commons Attribution License 4.0 (Attribution 4.0 International, CC BY 4.0)} This article is published under the terms of the Creative Commons Attribution License 4.0 https://creativecommons.org/licenses/by/4.0/deed.en $\underline{\underline{U S}}$

\section{$\underline{\text { Annex } 1}$}
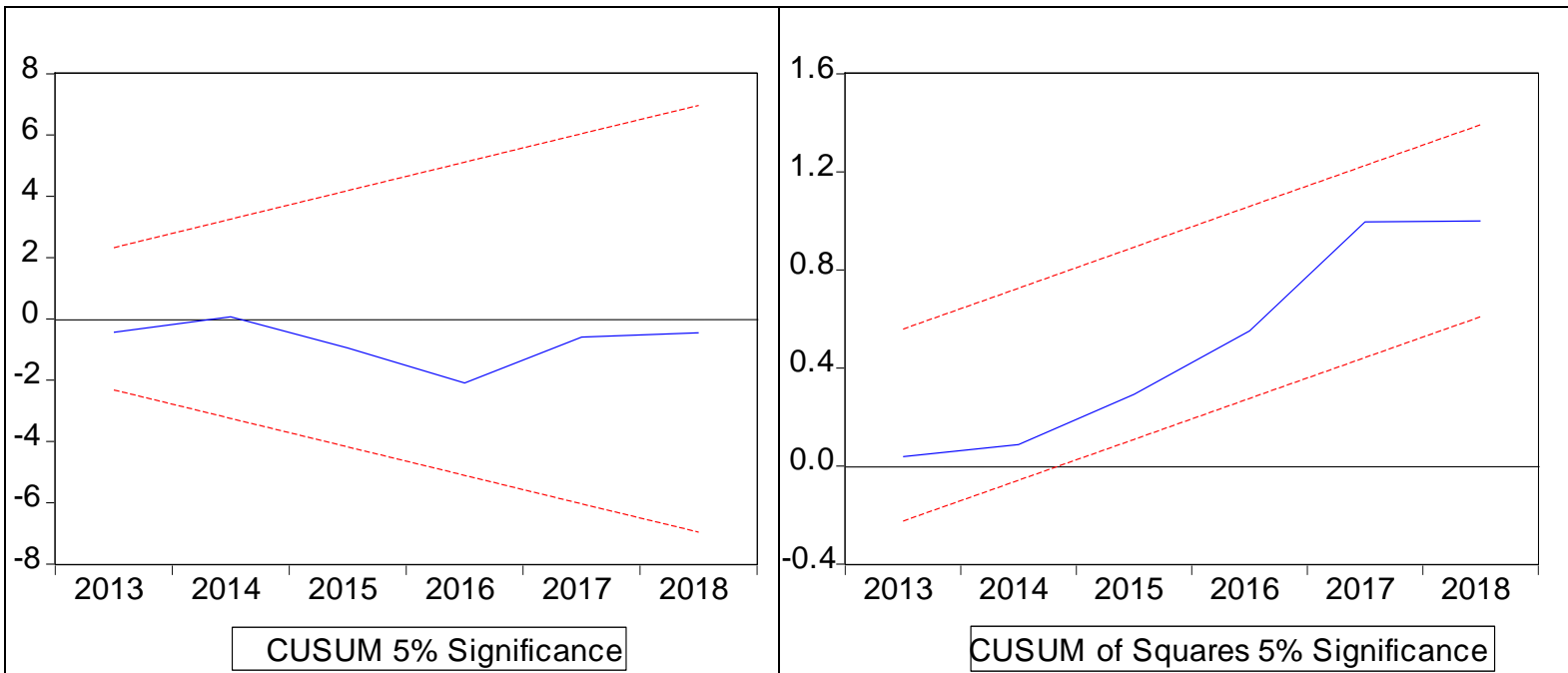